\title{
Overcoming Geographical Obstacles: The Use Of Skype In A Graduate-Level Social Media And Marketing Course
}

David J. Faulds, Ph.D, University of Louisville, USA

\begin{abstract}
This paper presents the results of a three-year research and teaching effort that focused on measuring the perceived effectiveness of Skype as a delivery platform for presentations made to students enrolled in a Professional MBA program by nationally acclaimed authors working in the area of social media. The research also investigated the authors' acceptance of Skype as a platform for delivering remote presentations to college audiences. The results indicated that both students and authors strongly supported the use of Skype as a presentation platform. The author presentations greatly enhanced the learning environment and contributed to achieving several specific course objectives.
\end{abstract}

Keywords: Skype; Synchronous Distance Education; Web-conferencing; Guest Speakers; Social Media

\section{INTRODUCTION}

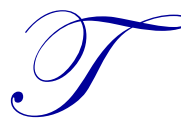

he value of including guest speakers as part of business classes has been well documented in the educational literature. These benefits include providing students with insights into issues involving the real-world business environment, the experiences of business practitioners (Faulds \& Mangold, 2014), the ways that textbook theory can apply to real-life aspects of business (Frontczak, 1998), and the enhancement of the experiential-learning character of the classroom (Zorek, Katz, \& Popovich, 2011).

Although the benefits of including this type of activity in classroom instruction have been acknowledged by the academic community, challenges inherent in identifying, coordinating, and scheduling speakers may discourage professors from utilizing this important resource. For example, the availability of qualified speakers for specific topics may be problematic, particularly for those teaching in universities located in smaller towns and cities or in rural or remote locations. Assuming appropriate local speakers can be identified, the task of coordinating travel and parking arrangements can also present logistical issues. Finally, integrating the speakers' schedules with the timing of relevant course topics often presents additional difficulties.

The primary objective of this paper is to describe the results of a three-year teaching and research effort that focused on using Skype as a platform to deliver remote presentations made by nationally recognized authors to an MBA-level Social Media and Marketing course. The attitudes and opinions of both the authors and students were collected through surveys and were analyzed to determine the usefulness of Skype as a method for communicating with graduate-level students. A second objective of the paper is to document how the presentations made by the authors contributed to accomplishing certain course objectives.

The results of this project suggest that many of the problems associated with incorporating guest speakers in business classes can be mitigated by using technology such as Skype. 


\section{THE SOCIAL MEDIA AND MARKETING COURSE}

The course is a 1.5-credit-hour elective offered in the evening Professional MBA program at a major state university located in a large Midwestern metropolitan area. The class meets one night per week for five consecutive weeks, and each 3.5-hour session is divided into three modules of approximately equal length. The first module consists of a presentation given by a practitioner from a local organization in charge of social media and marketing. The second module, which is the focus of this research, entailed Skype presentations (referred to as the Authors Forum) made by the authors of the assigned texts. Finally, the third module consists of lectures given by the professor on various social media and marketing issues related to the topics covered in the first two modules. Based on the student evaluations of the class, this format has proven to be highly successful. ${ }^{1}$

The goals established by the College of Business for the MBA program, the learning objectives, and the instructional activities for the course are presented in Appendix 1. As shown in the appendix, the Authors Forum presentations contributed to the achievement of multiple learning objectives that in turn were linked to various program goals (Burgess, 2012). The outcomes associated with the activities related to the presentations were evaluated using the rubrics presented in Appendix 2.

\section{SKYPE}

Skype is a free web-conferencing service provided by Microsoft that allows users to engage in a fully synchronous format from remote locations. The live interactive features of Skype allow an author to share PowerPoint slides, videos, and other visual materials with the class while the author and students simultaneously maintain "face-to-face" contact and audio communications. This form of web-conferencing software can greatly enhance the learning environment and contribute to the overall effectiveness in both traditional classroom-based instruction and more nontraditional methods of instruction such as remote learning (Botterill, 2011; Electronic Education Report, 2009; Ellis, 2009; McCrea, 2012; Terry, 2014).

The terraced classroom where the course met was equipped with an overhead projector, a remote-controlled screen, a computer with Internet connection, a web camera, microphones readily accessible to all students, and audio output devices. This setting provided an environment that optimized the full capabilities of Skype as a webconferencing platform. Skype can be successfully used across all computer and media platforms and requires very little technical expertise. For a more detailed description of Skype and for instructions on downloading the application, go to http://www.skype.com.

In a recent review of the benefits and challenges of using web-conferencing technologies such as Skype, Ellingson and Notbohm (2012) suggest that the benefits of using these technologies include "increased [student] motivation, preparation and participation; collaboration and community-building; use of technology; and convenience" (p. 559). The authors attributed these benefits in large part to the live interactive features of Skype, which afford synchronous communications among participants. Synchronous web-conferencing technologies like Skype have been found to "be more suitable for developing rapport amongst students and building a community of learners" (Parker, Boase-Jelinek, \& Herrington, 2011, p. 1) than asynchronous technologies. Hall and Herrington (2010) and others (Polhemus, Shih, Swan \& Richardson, 2000; Rourke, Anderson, Garrison, \& Archer, 2001) have attributed the success of these technologies to their ability to develop a spirit of "social presence" among users, which allows participants to "comfortably and effectively communicate through the technical medium" (p. 1012).

This sense of social presence in turn fosters increased dialogue, more communications, and a greater degree of commitment, engagement, and collaboration among group participants (Gunawardena, Wilson, \& Lopez, 2001; Richardson \& Swan, 2003). Synchronous web-conferencing technologies like Skype allow students to take control and responsibility for their learning and provide an environment that encourages higher-order thinking (Garrison, 1997).

\footnotetext{
${ }^{1}$ The syllabus is available from the author on request.
} 
A growing stream of research indicates that "technology-enriched learning environments" (Dabbagh \& Kitsantas, 2009, p. 154) can improve student learning and motivation and contribute to producing other positive educational outcomes. In a recent investigation, Charron and Raschke (2014) found that students who were assigned to use Skype in completing class activities in an accounting information systems course reported higher levels of perceived satisfaction with the course than those students who were not assigned to use Skype. In a quantitative management science course where a quasi-experimental design methodology that controlled for teaching method and the demographic characteristics of the test subjects was used, Strang (2012) reported that "the students in the synchronous Skype tutorials achieved a statistically higher number of substantive responses during weekly sessions and obtained a statistically higher final grade" (p. 18) than those students who did not use Skype.

The unique features of Skype were also found to greatly contribute to the success of an e-learning program that focused on teaching communications skills between U.S. and Taiwanese students (Mitchell, Chen, \& Medlin, 2010). In this cross-cultural program the authors found that the synchronous communication abilities offered by Skype enhanced various pedagogical outcomes established for the students, including problem-solving techniques, a better understanding of global issues and terminology, enhanced communication skills, an appreciation for diversity, self-assurance, and intercultural empathy and diplomacy. In another global study involving three universities, two based in the United States and one in India, Davis, Germonprez, Petter, Drum, and Kolstad (2009) reported that "the value of requiring the use of Skype was dramatic for some [student] teams" (p. 362) in successfully completing assigned tasks in a technology management course. Davis et al. concluded that the "lessons learned by both students and instructors [in this study] clearly showed the value of direct, personal communications" (p. 367) provided by Skype in managing and successfully completing technology development projects.

Synchronous teaching tools have been shown to improve outcomes across a variety of educational environments. However, Skype as a VoIP has yet to receive sufficient attention in the business education arena given its potential effectiveness in enhancing instructional outcomes. As Skype's use in higher education grows and its potential applications become more apparent (Ferenstein, 2010; McEleny, 2011; Educause, 2007), future research should focus on gauging Skype's effectiveness and value in higher education.

\section{PLANNING THE AUTHORS FORUM PRESENTATIONS}

As Faulds and Mangold (2014) note, readings from the popular business press offer "students more up-todate information, flexibility, affordability, and relevance" (p. 137) than do traditional academic textbooks. Following their recommendations, the most recent books from the popular business press were reviewed for the Social Media and Marketing course. Five books per semester were chosen for their breadth and depth in covering critical issues related to social media marketing. All of the books selected were recognized as the leading titles in this area, ${ }^{2}$ and their authors were invited to speak to the class via Skype. Table 1 provides the names of the various authors who participated over the three semesters when the course was offered, along with the book titles, author location, and presentation date.

\section{Contacting the Authors}

Before contacting the authors, information on each individual was gathered via an Internet search that included Facebook, LinkedIn, and other social media resources. The authors were first approached by e-mail informing them that their book had been selected as required reading in the course and inviting them to address the class via a Skype presentation. The e-mail also included a short description of the course, the number of students enrolled, and the students' respective employers. A request for telephone contact information and their preferences for the timing of an initial telephone conversation with the professor were also included.

After the professor received the above information, the authors were contacted by telephone and provided with more detailed information on the course and the nature of the presentation (Allen, 2009). Each author was given complete latitude in shaping the content and scope of the presentation and was encouraged to include a short

\footnotetext{
${ }^{2}$ A list of the books reviewed for inclusion in the course over the three-semester period but not included in Table 1 is available from the author on request.
} 
discussion of popular social media platforms and their applications in marketing, along with an overview of interesting emerging platforms and their uses in marketing as well. The authors were also asked to provide their opinions and thoughts on the future directions for the social media phenomenon. All of the authors contacted over the three semesters accepted the invitation to participate in the class.

Table 1. Participating Authors

\begin{tabular}{|c|c|c|c|}
\hline Author & Book \& Publisher & Author Location & $\begin{array}{c}\text { Presentation } \\
\text { Date }\end{array}$ \\
\hline${ }^{3}$ Burdon, Jonathan & SocialCoaster & Nashville, TN & Spring 2014 \\
\hline $\begin{array}{l}\text { Falls, Jason } \\
\quad \& \\
\text { Deckers, Erik }\end{array}$ & $\begin{array}{c}\text { No Bullshit Social Media: The All-Business, No- } \\
\text { Hype Guide to Social Media Marketing, Que } \\
\text { Publishing (2012) }\end{array}$ & $\begin{array}{l}\text { Louisville, KY } \\
\text { Indianapolis, IN }\end{array}$ & $\begin{array}{c}\text { Spring } 2013 \& \text { Spring } \\
2014 \\
\text { Summer } 2012\end{array}$ \\
\hline Gillin, Paul & $\begin{array}{c}\text { Secrets of Social Media Marketing: How to Use } \\
\text { Online Conversations and Customer Communities to } \\
\text { Turbo-Charge Your Business, Quill Driver Books } \\
\text { (2009) }\end{array}$ & Farmington, MA & Summer 2012 \\
\hline Gillin, Paul & $\begin{array}{c}\text { Attack of the Customers: Why Critics Assault } \\
\text { Brands Online and How to Avoid Becoming a } \\
\text { Victim of the Customers (2012) }\end{array}$ & Farmington, MA & $\begin{array}{c}\text { Spring } 2013 \& \text { Spring } \\
2014\end{array}$ \\
\hline Martin, Chuck & $\begin{array}{l}\text { The Third Screen: Marketing to Your Customers in } \\
\text { a World Gone Mobile, Nicholas Brealey Publishing } \\
\text { (2011) }\end{array}$ & Hanover, NH & Summer 2012 \\
\hline Martin, Chuck & $\begin{array}{c}\text { Mobile Influence: The New Power of the Consumer, } \\
\text { Palgrave Macmillan (2013) }\end{array}$ & Hanover, NH & Spring 2013 \\
\hline Rosen, Emanuel & $\begin{array}{c}\text { The Anatomy of Buzz Revisited: Real-life Lessons in } \\
\text { Word-of-Mouth Marketing, Doubleday (2009) }\end{array}$ & Palo Alto, CA & $\begin{array}{l}\text { Summer } 2012 \& \\
\text { Spring } 2013\end{array}$ \\
\hline Rosen, Emanuel & $\begin{array}{c}\text { Absolute Value: What Really Influences Customers } \\
\text { in the Age of (Nearly) Perfect Information, Harper } \\
\text { Collins (2014) }\end{array}$ & Palo Alto, CA & Spring 2014 \\
\hline Salt, Simon & $\begin{array}{l}\text { Social Location Marketing: Outshining Your } \\
\text { Competitors on Foursquare, Gowalla, Yelp \& Other } \\
\text { Location Sharing Sites, Que Publishing (2011) }\end{array}$ & Austin, TX & $\begin{array}{l}\text { Summer } 2012 \& \\
\text { Spring } 2013\end{array}$ \\
\hline Shankman, Peter & $\begin{array}{c}\text { Customer Service: New Rules for a Social Media } \\
\text { World, Que Publishing (2011) }\end{array}$ & New York, NY & Summer 2012 \\
\hline Stratten, Scott & $\begin{array}{l}\text { UNMarketing: Stop Marketing. Start Engaging. } \\
\text { John Wiley \& Sons, Inc. (2012) }\end{array}$ & Toronto, Canada & Spring 2014 \\
\hline
\end{tabular}

Finally, in a follow-up e-mail correspondence, each author was queried concerning preferences for a presentation date. Once the final schedule was confirmed, the author was requested to provide a general description of the content of the presentation and information on whether it would include PowerPoint slides, video material, or other visual enhancements, along with information on the author's familiarity and experiences with Skype. Permission was obtained from each author to post contact information (an e-mail address, telephone number, and mailing address) on the class Blackboard page.

\section{Pilot Testing the Presentation}

Several days before each scheduled presentation, a pilot test was conducted with the author, professor, and an information technology specialist from the host university, using the classroom where the course was scheduled to meet. The IT specialist was present to answer any questions from the author or resolve any technology-related issues. On the date of the presentation, a brief pilot session was held prior to the beginning of the class. Finally, the IT specialist was present during the presentation to resolve any unforeseen problems.

${ }^{3}$ Jonathan Burdon created the social media platform SocialCoaster. 


\section{Presentations}

The five presentations made per semester averaged 60 minutes in length including a spirited question-andanswer session. In all cases the authors discussed material not covered in their book. Each author offered a short discussion of the information the professor had requested, which included a summary of the popular social media platforms and their applications in marketing as well as an overview of interesting emerging platforms and their uses in marketing. The authors also discussed their opinions and thoughts on the future directions for the social media phenomenon.

The presentation topics included the uses of social media in service recovery, the importance of consumer ratings and reviews, and the impact of mobile shopping on consumer behavior and its effect on retailing, to name a few.

\section{METHOD}

To address the primary objective of the research, two survey instruments were developed. The first focused on collecting information from the students in each class and consisted of both open-ended questions and 18 statements with responses based on a Likert scale, with 1 being Strongly Disagree and 5 representing Strongly Agree. The statements were intended to measure the students' perceptions of the effectiveness of Skype as a delivery platform for the presentations, their perceived benefits from incorporating the Authors Forum presentations into the course via Skype, and the extent to which these presentations contributed to accomplishing specific course objectives. The statements included a mixture of items adopted from previous research (Bobbitt, Inks, Kemp, \& Mayo, 2000; Elam \& Spotts, 2004; Li, Greenburg \& Nicholls, 2007; Kaplan, Piskin, \& Bol, 2010; Zorek, Katz, \& Popovich, 2011) and other items designed exclusively for this study. The final survey question measured students' overall enthusiasm for the course using the Net Promoter Score developed by Reichheld (2003).

The reliability analysis for the items included in the questionnaire generated a Cronback Alpha score of .93 for the 2012 course offering, and .91 and .92 for the 2013 and 2014 offerings, respectively. The internal consistency of the items exceeds the minimum level for internal reliability of .70 as specified by Nunnally (1978).

The second questionnaire focused on the authors' opinions and observations on the use of Skype to deliver their presentations. Information concerning their previous speaking experiences with college audiences and their likelihood of accepting future speaking engagements that utilize Skype was also collected.

After careful pretesting, both questionnaires were submitted to the university's Human Subjects Committee for approval. After receiving approval, the student questionnaire was circulated on the last day of class, and students were allotted ten minutes of time to complete and return it. The student response rate was 100 percent for the first two course offerings and 95 percent (19 out of 20 students) for the spring semester 2014. The author survey was sent to each individual via e-mail following the first presentation. Seven of the nine authors participating in the Authors Forum presentations completed and returned the questionnaire.

\section{RESULTS}

Table 2 contains the student responses to the quantitative questions on the survey, and their comments to the two qualitative questions (Q7 and Q8) are presented in Table 3. Taken together, the information contained in these two tables indicates that (1) students perceived Skype as an effective platform for delivering remote presentations, (2) the Authors Forum series, delivered via Skype, enhanced students' overall learning experience and enjoyment of the class, and (3) the presentations helped accomplish certain course objectives.

Table 2 compares the mean score of each statement to the neutral midpoint (i.e., 3). Any significant difference from the midpoint implies an inclination to a non-neutral position. The results of the t-tests show that the means of the items are significantly greater than the midpoint at $\alpha=0.05$. The students indicated that Skype and the presentations made via this platform enhanced the overall quality of the learning experience (Q9 and Q14), were 
more informative and enjoyable than a class lecture (Q15 and Q16), and contributed to their overall satisfaction with the class (Q20 and Q23). The Net Promoter Score suggests a high degree of satisfaction with the course in general.

The Authors Forum presentations were also instrumental in accomplishing two specific course objectives. In Q12, the students indicated that the presentations enhanced their understanding of the uses of social media in marketing, which was a direct objective for the course. The responses to Q10 and Q11 indicate that the presentations piqued the students' interest in social media and would lead them to read more on the subject. Another course objective, to improve the students' oral and written communication skills, was achieved, as shown by the responses to Q24 and Q25. Finally, the students felt that the Skype presentations contributed to accomplishing the overall learning objectives established for the course (Q21).

One surprising result emerging from the data in Table 2 is that three Professional MBA class cohorts, consisting of a total of 90 students, not a single previous class had used Skype as a vehicle for incorporating guest speakers (see Q5). However, as indicated in Q13, students would encourage the use of Skype or a similar technology as a means of incorporating speakers in other courses. Finally, the pattern of responses to the statements across the three-semester timeframe reveals a general upward and favorable trend in the preferences for the Skype-delivered Authors Forum presentations.

The qualitative information in Table 3 also strongly supports the usefulness of Skype as a delivery platform to incorporate guest speakers in business classes. Table 3 contains generalized summaries based on the statements students made concerning their likes and dislikes regarding the Authors Forum series. Specific comments, which are presented in quotation marks, refer to specific student statements concerning their perceptions of the usefulness of Skype as a delivery platform. The distillation of this information can be generalized in three points. First, the students enjoyed meeting and engaging with nationally acclaimed authors. Second, the discussions greatly enhanced the learning environment. Finally, Skype was found to be an appropriate technology for delivering remote presentations.

In addition to soliciting the students' responses to the Authors Forum series, the nine participating authors were surveyed to ascertain their opinions and thoughts on Skype as a delivery platform and the likelihood of their participation in future university classes that utilize Skype. As can be seen in Table 4, five of the seven authors who responded to the survey had not previously used Skype for presentations to university classes (see Q3). Overall, the authors enjoyed speaking to college and university classes (Q6) and indicated a high likelihood of accepting future invitations to speak to university audiences via Skype (Q7). The authors also found Skype to be a convenient and relatively easy method to engage with students (Q4). 
Table 2. Summary Of Responses To Quantitative Survey Questions

\begin{tabular}{|c|c|c|c|c|}
\hline Question Number & $\begin{array}{l}\text { Summer } \\
2012\end{array}$ & $\begin{array}{l}\text { Spring } \\
2013\end{array}$ & $\begin{array}{l}\text { Spring } \\
2014\end{array}$ & Total \\
\hline $\begin{array}{l}\text { Q1. Gender: } \\
\text { Female } \\
\text { Male }\end{array}$ & $\begin{array}{l}16 \\
17\end{array}$ & $\begin{array}{l}16 \\
21\end{array}$ & $\begin{array}{c}6 \\
14\end{array}$ & $\begin{array}{l}38 \\
52\end{array}$ \\
\hline $\begin{array}{l}\text { Q3. Have you employed Skype or a similar technology in your personal or } \\
\text { professional communications? } \\
\text { Yes } \\
\text { No }\end{array}$ & $\begin{array}{c}28 \\
5\end{array}$ & $\begin{array}{c}28 \\
9\end{array}$ & $\begin{array}{c}9 \\
11\end{array}$ & $\begin{array}{l}65 \\
25\end{array}$ \\
\hline $\begin{array}{l}\text { Q4. The use of Skype in this class has stimulated my interest in using this } \\
\text { technology for my own personal or professional communications. }\end{array}$ & 4.09 & 3.73 & 4.50 & 4.04 \\
\hline $\begin{array}{l}\text { Q5. Has Skype or a similar technology been used in any of your previous classes to } \\
\text { deliver presentations by guest speakers? } \\
\text { Yes } \\
\text { No }\end{array}$ & $\begin{array}{l}00 \\
33\end{array}$ & $\begin{array}{l}00 \\
37\end{array}$ & $\begin{array}{l}00 \\
20\end{array}$ & $\begin{array}{l}00 \\
90\end{array}$ \\
\hline $\begin{array}{l}\text { Q9. I feel that incorporating the authors' presentations into the class via Skype } \\
\text { enhanced the learning experience. }\end{array}$ & 4.60 & 4.54 & 4.85 & 4.63 \\
\hline $\begin{array}{l}\text { Q10. The authors' Skype presentations stimulated my interest in the uses of social } \\
\text { media in marketing. }\end{array}$ & 4.40 & 4.46 & 4.75 & 4.50 \\
\hline $\begin{array}{l}\text { Q11. The authors' Skype presentations will lead me to read more on the } \\
\text { applications of social media in marketing. }\end{array}$ & 4.20 & 3.95 & 4.65 & 4.20 \\
\hline $\begin{array}{l}\text { Q12. The authors' Skype presentations enhanced my understanding of the uses of } \\
\text { social media in marketing. }\end{array}$ & 4.50 & 4.40 & 4.90 & 4.54 \\
\hline $\begin{array}{l}\text { Q13. Future classes in the MBA program should use Skype or a similar technology } \\
\text { as a means to incorporate guest speakers into the course. }\end{array}$ & 4.56 & 4.24 & 4.80 & 4.50 \\
\hline $\begin{array}{l}\text { Q14. The Skype presentations were important to the overall quality of the learning } \\
\text { experience. }\end{array}$ & 4.53 & 4.27 & 4.80 & 4.48 \\
\hline $\begin{array}{l}\text { Q15. As a learning experience, the Skype presentations were more informative } \\
\text { than listening to a lecture. }\end{array}$ & 4.40 & 4.37 & 4.40 & 4.38 \\
\hline $\begin{array}{l}\text { Q16. As a learning experience, the Skype presentations were more enjoyable than } \\
\text { listening to a lecture. }\end{array}$ & 4.53 & 4.24 & 4.25 & 4.34 \\
\hline $\begin{array}{l}\text { Q17. I valued the opportunity to interact with leading social media experts through } \\
\text { the use of Skype in this class. }\end{array}$ & 4.62 & 4.48 & 4.90 & 4.63 \\
\hline $\begin{array}{l}\text { Q18. The Skype presentations provided me an opportunity to develop my } \\
\text { professional network. }\end{array}$ & 4.06 & 3.70 & 4.10 & 3.92 \\
\hline $\begin{array}{l}\text { Q19. The information presented by the authors via Skype reinforced the concepts } \\
\text { covered in the class lectures. }\end{array}$ & 4.34 & 4.13 & 4.70 & 4.34 \\
\hline Q20. The Skype presentations enhanced my overall satisfaction with the course. & 4.68 & 4.32 & 4.75 & 4.55 \\
\hline $\begin{array}{l}\text { Q21. The Authors Forum presentations delivered via Skype contributed to } \\
\text { accomplishing the course objectives. }\end{array}$ & 4.65 & 4.37 & 4.80 & 4.57 \\
\hline $\begin{array}{l}\text { Q22. I believe that the Authors Forum presentations delivered via Skype were an } \\
\text { effective use of class time in this course. }\end{array}$ & 4.68 & 4.37 & 4.90 & 4.61 \\
\hline $\begin{array}{l}\text { Q23. The Authors Forum presentations delivered via Skype were one of the best } \\
\text { components of this class. }\end{array}$ & 4.59 & 4.37 & 4.65 & 4.52 \\
\hline $\begin{array}{l}\text { Q24. Listening to the Authors Forum Skype presentations allowed me to improve } \\
\text { the quality of my written book report. }\end{array}$ & 4.18 & 3.97 & 4.55 & 4.14 \\
\hline $\begin{array}{l}\text { Q25. Writing about the Authors Forum Skype presentations in my logbook } \\
\text { broadened my understanding of social media and its applications to marketing. }\end{array}$ & 4.00 & 4.10 & 4.65 & 4.18 \\
\hline Q26. ${ }^{4}$ Net Promoter Score. & $75.75 \%$ & $72.97 \%$ & $95.00 \%$ & $77.77 \%$ \\
\hline $\begin{array}{l}\text { Summary: } \\
\text { Sample Size } \\
\text { Response Rate } \\
\text { Cronback Alpha } \\
\text { Note: Ho: } \mu=3 ; \text { Ha: } \mu \neq 3 \text {; significant at } \alpha=.05, p \text {-value in parentheses } \\
\text { Scale: Strongly Disagree }=1 \text {, Disagree }=2 \text {, Neutral }=3 \text {, Agree }=4 \text {, Strongly Agree }=5\end{array}$ & $\begin{array}{l}33 \\
100 \% \\
0.93\end{array}$ & $\begin{array}{c}37 \\
100 \% \\
0.91\end{array}$ & $\begin{array}{l}20 \\
95 \% \\
0.92\end{array}$ & $\begin{array}{l}90 \\
98.90 \% \\
0.93\end{array}$ \\
\hline
\end{tabular}

${ }^{4}$ The instructions for question 26 stated "Please answer the following question on the scale 0 to 10 , where 0 is "Not at all Likely to Recommend" and 10 is "Extremely Likely to Recommend," with 5 being the "Neutral" point." The question read "___ Based on your experience with the class, how likely is it that you would recommend to another student a class that uses Skype for the delivery of presentations by experts?" 
Table 3. Summary of Qualitative Responses to Survey Questions

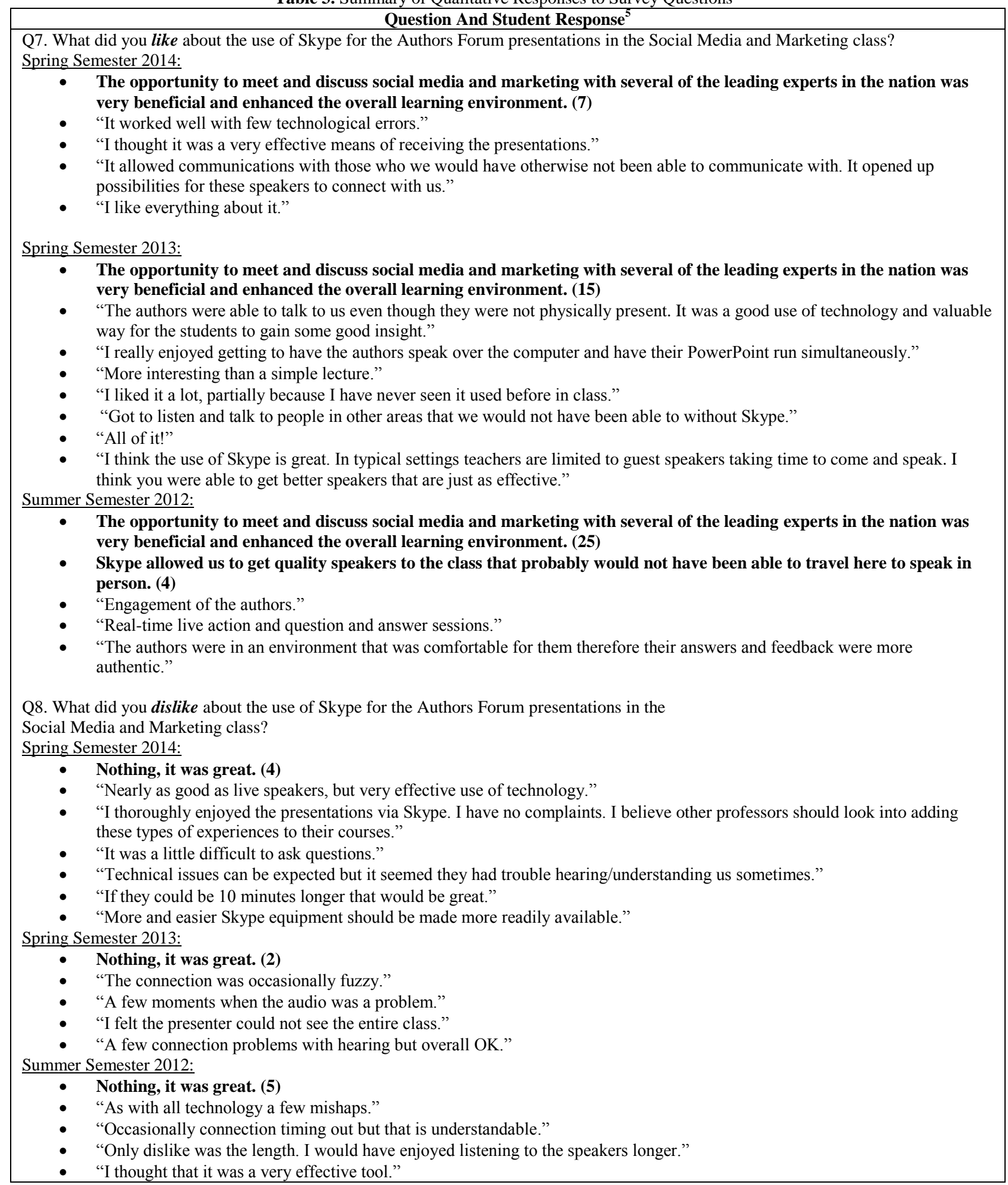
Table 4. Responses To Author Survey

\footnotetext{
${ }^{5}$ The generalized comments appear in bold print and represent a summary of student opinions. The number in parenthesis represents the number
} of times that comment or a very similar comment was made. Specific comments appear in quotation marks. 


\begin{tabular}{|c|c|}
\hline Question Number & Response \\
\hline $\begin{array}{l}\text { Q1. Before speaking to the MBA class at the (name of university), had you made presentations related to social media to } \\
\text { college or university classes? } \\
\text { Yes } \\
\text { No }\end{array}$ & $\begin{array}{l}7 \\
0\end{array}$ \\
\hline $\begin{array}{l}\text { Q2. If you answered "Yes" to the above question, how many presentations have you made to college or university } \\
\text { classes? } \\
\text { Number of respondents: } 1 \\
1 \\
4 \\
1\end{array}$ & $\begin{array}{c}25 \\
10-15 \\
10+ \\
5-7\end{array}$ \\
\hline $\begin{array}{l}\text { Q3. Prior to the (name of university) MBA class presentation, had you ever used Skype or a similar technology to make } \\
\text { a remote presentation to a college or university class? } \\
\text { Yes } \\
\text { No }\end{array}$ & $\begin{array}{l}2 \\
5\end{array}$ \\
\hline Q6. I enjoy speaking to college and university classes on topics related to social media. & 4.71 \\
\hline $\begin{array}{l}\text { Q7. I am likely to accept future invitations to speak to a college or university class in which I would use Skype, or a } \\
\text { similar technology, to make the presentation. }\end{array}$ & 4.28 \\
\hline $\begin{array}{l}\text { Q8. I believe the use of Skype or similar technologies have great potential in the delivery of college and university } \\
\text { classes. }\end{array}$ & 4.57 \\
\hline $\begin{array}{l}\text { Q9. Presentations delivered via Skype or similar technologies in college and university classes can help authors and } \\
\text { other social media experts contribute to students' learning experiences. }\end{array}$ & 4.43 \\
\hline $\begin{array}{l}\text { Q10. Overall, the use of Skype for my presentation in the (name of university) class enabled me to effectively } \\
\text { communicate with the students. }\end{array}$ & 3.71 \\
\hline $\begin{array}{l}\text { Q4. What did you like about the use of Skype for the (name of university) MBA class presentation? } \\
\text { - Nice to be able to engage with students. } \\
\text { - It allowed me to connect with the class in a remote setting much more easily than just an audio presentation } \\
\text { - } \text { - Could have done. } \\
\text { - No technience } \\
\text { - Very convenient. I could make the presentation from my home office with no travel problems. } \\
\text { - I enjoyed being part of the class and the interest the students displayed in my subject and book. }\end{array}$ & \\
\hline $\begin{array}{l}\text { Q5. What did you dislike about the use of Skype for the (name of university) MBA class presentation? } \\
\text { - Nothing } \\
\text { - It can be difficult to see all the students at once or who is responding to questions. } \\
\text { - Nometimes it was difficult to hear questions. } \\
\text { Sample Size: } 7 \text { of } 9 \text { total authors; Response Rate: } 77.77 \% \text {; Test of significance not calculated. } \\
\text { Scale: (Q6 to Q10) Strongly Disagree=1, Disagree }=2, \text { Neutral=3, Agree }=4 \text {, Strongly Agree=5 }\end{array}$ & \\
\hline
\end{tabular}

\section{LESSONS LEARNED}

This innovative class activity has clearly produced a number of positive outcomes. However, the success of any class activity requires careful preparation and meticulous attention to detail. The following observations summarize the lessons learned over a three-semester period in offering the course.

- $\quad$ The Authors Forum presentations delivered via Skype resulted in active engagement from both authors and students, and provided students an opportunity to meet and exchange ideas, opinions, and thoughts with nationally recognized experts in the field of social media marketing.

- $\quad$ All nine authors were extremely cooperative and enthusiastic about the opportunity to engage with students enrolled in a Professional MBA program.

- $\quad$ The presentations by the authors should be scheduled at least two months in advance.

- In the initial communications with authors, the course should be clearly described, student profiles should be provided, and alternative dates for the presentations should be articulated.

- In follow-up communications, contact information for the authors should be collected, including e-mail address, telephone number, and postal address. Permission to share this information with the students should be obtained. 
- $\quad$ The presentation should be pilot tested several days prior to the actual presentation date, followed by a short test of the Skype delivery system the day of the presentation. A university IT specialist should be on hand to assist with technical issues.

- $\quad$ The students should be encouraged to send a thank you e-mail note to each author and write a review of the authors' book for posting on Amazon.com and other review sites.

- $\quad$ The Authors Forum presentations should be linked to program goals and class objectives.

\section{LIMITATIONS AND DIRECTIONS FOR FUTURE RESEARCH}

As the first known study to appear in the business education literature that focuses on the use of Skype in a graduate-level professional MBA course, this study reinforces the need for additional research in the applications of web-conferencing technologies in graduate-level business programs and business education in general. Although the incorporation of the Authors Forum series in the class was evaluated as highly successful by all participants-authors, professor, and students--the study has several limitations. First, because the students in the study were enrolled in a Professional MBA course and were older with several years of full-time work experience, they likely differ from a traditional undergraduate population in the way they respond to class activities such as the Authors Forum series. Therefore, the results reported in this investigation may not necessarily be replicable in other student populations or educational settings.

Second, the content of the social media and marketing course may itself have been more conducive to creating an environment where web-conferencing synchronous technologies would be more favorably received than in other general business classes. Given the fact that this was the first class where students enrolled in the MBA program encountered the use of Skype as an integral component of the course, there may have been a "novelty" effect in play that enhanced their perceptions of the value and quality of this technology in improving the learning experience. In institutions where the use of web-conferencing technologies in the classroom is more prevalent, students may not respond as favorably as they did in this study.

A closely related issue, a "status" effect, may have been present as a result of the national reputation of the participating authors. Embedding such individuals in the course may have increased the anticipation and expectations the students brought to the class and may have contributed to their overall positive assessment of this activity. This could account for the upward and favorable response the Authors Forum received from students over the three-semester time frame in which the study was conducted.

Some of the limitations of this study could be addressed using a quasi-experimental research design that controls for the numerous factors described above. Future research should continue to explore the value of webconferencing technologies in the delivery of business education, in various pedagogical settings, among diverse student populations, and across different student learning styles.

\section{CONCLUSION}

This study documented the results of a three-year teaching-and-research effort that focused on determining the effectiveness of Skype as a delivery platform for incorporating presentations made by nationally acclaimed authors to a graduate-level business class. Three important outcomes were found: first, the national experts generously contributed their time and expertise for this classroom activity; second, Skype was found by both authors and students to be an effective means for delivering presentations; and, third, the presentations contributed to achieving specific course objectives.

Of the six learning objectives established for the course (see Appendix 1), three were directly addressed by the Authors Forum series which employed Skype: (1) Know the applications of various social media venues to marketing, (2) Explain how organizations integrate social media with other elements of the promotion mix, and (5) Apply written and oral communication skills effectively. The quantitative information contained in Table 2 and the qualitative survey responses summarized in Table 3 both indicate that the students strongly agreed that the Authors Forum series contributed to accomplishing the above three objectives. Specifically, the data presented in Table 2 for 
questions $10,11,12,24$, and 25 provide evidence that this class activity did contribute to accomplishing the three objectives shaded in Appendix 1.

One important implication of this research is that educators can more confidently utilize Skype as a platform for the delivery of presentations made by speakers from remote locations. In this study, individuals from cities such as Palo Alto, California; Farmington, Massachusetts; Toronto, Canada; and Austin, Texas could readily engage in face-to-face, synchronous communications in-real time with students located in a midwestern university. For institutions located in smaller cities or rural areas, Skype may provide a technology that educators can use to include guest speakers in their class offerings.

Finally, given the enthusiastic response and cooperation received from all nine authors who participated in the course, educators should consider reaching out to writers drawn from the popular business press, other types of experts, and leading business practitioners as potential guest speakers in their graduate-level courses. Webconferencing technologies such as Skype provide a simple yet highly effective means for overcoming the geographical obstacles that once prevented educators from including such individuals in their classes.

\section{AUTHOR INFORMATION}

David J. Faulds received his PhD at the University of Iowa and is an Associate Professor in the College of Business Administration at the University of Louisville. His teaching interests are in the areas of social media and marketing, services marketing, marketing research, and marketing analytics. He has published in the Journal of Consumer Research, Journal of Services Marketing, Journal of Industrial Marketing Management, Marketing Education Review, Business Horizons, and Journal of Industrial Organization. Prior to joining the faculty at the University of Louisville, he served on the faculty at the University of Tennessee (Knoxville) and the University of Oregon (Eugene).

\section{REFERENCES}

Allen, M. (2009). Improving Student Outcomes Using Web2.0 Concepts and a Knowledge-Networking Approach.

Link: ALTC Fellowship Learning in Network of Knowledge Website.

Allen, S. (2009). Five tips to Help Guest Lecturers Succeed. Teaching Professor, 23(8), 4.

Anderson, T. (2008). Towards a Theory of Online Learning. In T. Anderson (Ed.), The Theory and Practice of Online Learning $\left(2^{\text {nd }} E d\right)$. Edmonton, Canada: Athabasca University Press, 45-74.

Bobbitt, L. M., Inks, S. A., Kemp K. J., \& Mayo, D. T. (2000). Integrating Marketing Courses to Enhance TeamBased Experiential Learning. Journal of Marketing Education, 22(1), 15-24.

Burgess, B. (2012). Pop-up Retailing: The Design, Implementation, and Five-Year Evolution of an Experiential Learning Project. Journal of Marketing Education, 34(3), 284-296.

Charron, K., \& Raschke, R. (2014). Student Perception and Experiences Using Jing and Skype in an Accounting Information Systems Class. Journal of Education for Business, 89, 1-6.

Dabbahh, N., \& Kitsantas, A. (2009). Exploring How Experienced Online Instructors Report Using Integrative Technologies to Support Self-Regulated Learning. International Journal of Technology in Teaching and Learning, 5(2), 154-168.

Davis, A., Germonprez, M., Petter, S., Drum, D., \& Kolstad, J. (2009). A Case Study of Offshore Development Across IS Courses: Lessons Learned from a Global Student Project. Communications of the Association for Information Systems, 24(21), 351-372.

Ellingson, D. E., \& Notbohm, M. (2012). Synchronous Distance Education: Using Web-Conferencing in an MBA Accounting Course. American Journal of Business Education, 5(5), 555-561.

Falls, J., \& Deckers, E. (2012). No Bullshit Social Media. Indianapolis, Indiana: Que Publishing.

Faulds, D. J., \& Mangold, W. G. (2014). Developing a Social Media and Marketing Course. Marketing Education Review, 24(2), 127-144.

Frontczak, N. (1998). A Paradigm for the Selection, Use and Development of Experiential Learning Activities in Marketing Education. Marketing Education Review, 8(Fall), 25-33.

Garrison D. R. (1997). Computer Conferencing: The Post-Industrial Age of Distance Education. Open Learning: The Journal of Open, Distance and E-Learning. 12(2), 3-11. 
Gillin, P., \& Gianforte, G. (2012). Attack of the Customers. Charleston, South Carolina.

Gillin, P. (2009). Secrets of Social Media Marketing. Fresno, California: Quill Driver Books.

Gunawardena, N., Wilson, P. L., \& Lopez, J.R. (2001). A Cross-Cultural Study of Group Process and Development in Online Conferences. Distance Education, 22(1), 85-122.

Hall, A., \& Herrington J. (2010). The Development of Social Presence in Online Arabic Learning Communities. Australasian Journal of Education Technology, 26(7), 1012-1027.

Kaplan, M. D., Piskin, B., \& Bol, B. (2009). Educational Blogging: Integrating Technology into Marketing Experience. Journal of Marketing Education, 32(May), 50-63.

Li, T., Greenberg, B. A., \& Nicholls, J. A. (2007). Teaching Experiential Learning: Adoption of an Innovation Course in an MBA Curriculum. Journal of Marketing Education, 29(1), 25-33.

Martin, C. (2011). The Third Screen: Marketing to Your Customers in a World Gone Mobile. Boston, Massachusetts: Nicholas Brealey Publication.

Martin, C. (2013). Mobile Influence: The New Power of the Consumer. New York: Palgrave Macmillan.

McCrea, B. (2012). Skype Takes Student Where No School Bus Can Go. $21^{\text {st }}$ Century School, June/July $2012,1$.

McEleny, C. (2011). Skype Targets Teachers with Community for Online Schools, NMA, (January), 6.

Mitchell, A., Chen, C., \& Medlin, B. Dawn. (2010). Teaching and Learning with Skype. Cutting Edge Social Media Social Media Approaches to Business Education: Teaching with LinkedIn, Facebook, Twitter, Second Life, and Blogs. Charlotte, NC: Information Age Publishing, 39-56.

Nunnally, J. C. (1978). Psychometric Theory. New York: McGraw-Hill.

Panye, N. J., Campbell, C., Ball A. S., \& Piercy, N. (2011). Placing a Hand in Fire: Assessing the Impact of a YouTube Experiential Learning Project on Viral Marketing Knowledge Acquisition. Journal of Marketing Education, 33(May), 204-216.

Parker, J., Boase-Jelinek, D., \& Herrington, J. Perceptions and Reflections: Using Skype Chat to Build a Community of Learners. Proceedings of World Conference on E-Learning in Corporate, Government, Healthcare, and Higher Education, 1599-1604.

Pete, A. (2011). How Skype Is Leading the Online Education Phenomena: A Chat with Jacqueline Botterill (Part 1 \& 2), Twitchange: How Social Media Is Changing the World, (November 22), 1-3.

Polhemus, L., Shih, L.-F., Swan, K., \& Richardson, J. (2000). Building Affective Learning Community: Social Presence \& Learning Engagement. Paper presented at the World Conference on the WWW and Internet. 800-802.

Reichheld, F. F. (2003). The One Number You Need to Grow. Harvard Business Review, December, 1-9.

Richardson, J., \& Swan, K. (2003). Examining Social Presence in Online Courses in Relation to Students' Perceived Learning and Satisfaction. Journal of Asynchronous Learning Networks, 7(1), 68-88.

Rosen, E. (2009). The Anatomy of Buzz Revisited: Real-life lessons in Word-of-Mouth Marketing. New York: Doubleday Publications.

Rourke, L., Anderson, T., Garrison, D. R., \& Archer, W. (2001). Assessing social presence in asynchronous textbased computer conferencing. Journal of Distance Education, 14(2), 1-17.

Salt, S. (2011). Social Location Marketing. Indianapolis, Indiana: Que Publishing.

Shankman, P. (2011). Customer Service: New Rules for a Social Media World Service. Indianapolis, Indiana: Que Publishing.

Simonson, I., \& Rosen, E. (2014). Absolute Value. New York: Harper Collins Publishers.

Strang, D. K. (2012). Skype Synchronous Interaction Effectiveness in a Quantitative Management Science Course. Decision Sciences Journal of Innovative Education, 10(1), 3-23.

Stratten, S. (2012). UN Marketing: Stop Marketing. Start Engaging. Hoboken, New Jersey: John Wiley \& Sons, Inc. Terry, J. (2014). 50 Awesome Ways to Use Skype in the Classroom. Teaching Degree.org, 1-6.

Zorek, J. A., Katz, N. L., \& Popovich, N. G., (2011). Instructional Design and Assessment: Guest Speakers in a Professional Development Seminar Series. American Journal of Pharmaceutical Education, 75(2) Article 2. 


\section{APPENDIX 1. PROGRAM GOALS, LEARNING OBJECTIVES, AND INSTRUCTIONAL ACTIVITIES}

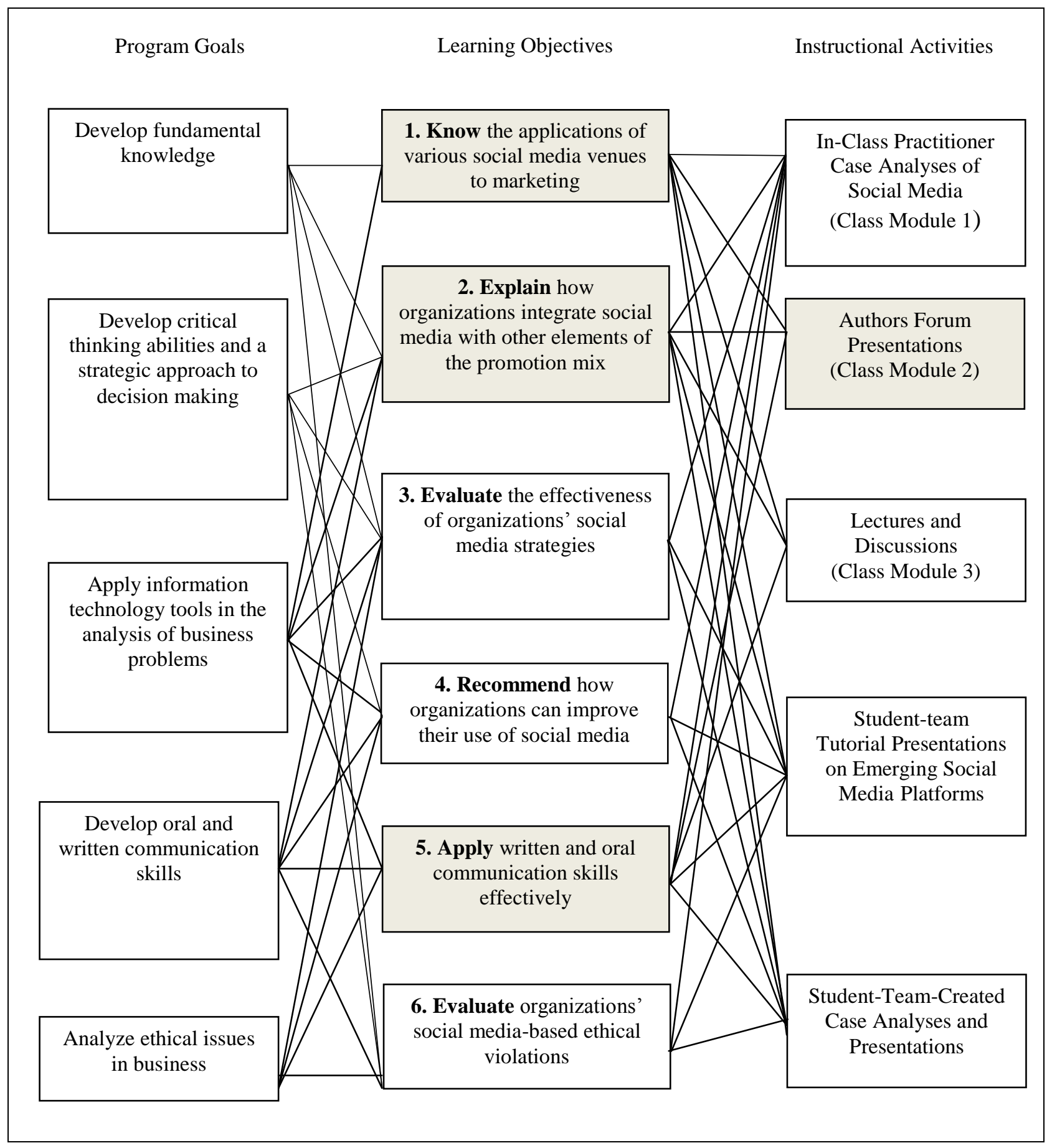

Note: The Learning Objectives directly related to the Authors Forum presentations are highlighted.

Source: Adapted from, Faulds, D.J., \& Mangold W.G. (2014). Developing a Social Media and Marketing Course. Marketing Education Review, 24(2), 132. 


\section{Instructional Activities}

The class activities are divided into three modules. The focus of this paper is on Module 2, the Authors Forum Presentations, and the assignments that relate to this module are as follows.

- $\quad$ Authors Forum Logbook. Students maintain a logbook that includes their observations, thoughts, and insights on each speaker in the Authors Forum presentation series.

- Book Reviews. Students are required to prepare a book review for each of the assigned books. The book reviews address the strengths and weaknesses of the book, perspectives and background of the author(s), the book's main points, an overall evaluation, and any other thoughts or observations about the book.

- Case Analysis of Emerging Social Media Venues. For each new social media platform discussed by the authors students are required to write a two page typewritten analysis of the venue and its applications to marketing. In addition, students are required to use the venue and discuss their thoughts and observations on the functionality of the platform.

- $\quad$ Student-Team Social Media Tutorial Presentations. Student teams present an in-class tutorial on a recently introduced social media venue not discussed by the authors. These presentations emphasize the working mechanics and marketing applications of the social media venue and highlight organizations that are using the social media platform in their marketing efforts. 


\section{APPENDIX 2. GRADING RUBRIC}

\begin{tabular}{|c|c|c|c|}
\hline \multicolumn{4}{|c|}{ Grading Rubric: Book Review and Authors Forum Logbook } \\
\hline Category & 1 & 2 & 3 \\
\hline $\begin{array}{l}\text { Discussion of the main } \\
\text { points of the book, including } \\
\text { its strengths and weaknesses }\end{array}$ & $\begin{array}{l}\text { The discussion did not } \\
\text { describe the main points of } \\
\text { the book or its strengths and } \\
\text { weaknesses }\end{array}$ & $\begin{array}{l}\text { The discussion included only } \\
\text { a few of the main points of } \\
\text { the book and its strengths } \\
\text { and weaknesses }\end{array}$ & $\begin{array}{l}\text { The discussion included } \\
\text { most or all of the main points } \\
\text { of the book as well as its } \\
\text { strengths and weaknesses }\end{array}$ \\
\hline $\begin{array}{l}\text { Discussion of the } \\
\text { professional background and } \\
\text { perspectives of the author(s) }\end{array}$ & $\begin{array}{l}\text { The discussion failed to } \\
\text { include the professional } \\
\text { background and perspectives } \\
\text { of the author(s) }\end{array}$ & $\begin{array}{l}\text { The discussion included only } \\
\text { a partial review of the } \\
\text { professional background and } \\
\text { perspectives of the author(s) }\end{array}$ & $\begin{array}{l}\text { The discussion included a } \\
\text { complete review of the } \\
\text { professional background and } \\
\text { perspectives of the author(s) }\end{array}$ \\
\hline $\begin{array}{l}\text { Discussion of the strategic } \\
\text { and tactical relevance of the } \\
\text { book to marketing }\end{array}$ & $\begin{array}{l}\text { The discussion did not } \\
\text { address the strategic or } \\
\text { tactical relevance of the book } \\
\text { to marketing }\end{array}$ & $\begin{array}{l}\text { The discussion included only } \\
\text { a partial analysis of the } \\
\text { strategic or tactical relevance } \\
\text { of the book to marketing }\end{array}$ & $\begin{array}{l}\text { The discussion included a } \\
\text { thorough analysis of the } \\
\text { strategic or tactical relevance } \\
\text { of the book to marketing }\end{array}$ \\
\hline $\begin{array}{l}\text { Incorporation of students' } \\
\text { thoughts, opinions, and } \\
\text { experiences as part of the } \\
\text { review process }\end{array}$ & $\begin{array}{l}\text { The student did not include } \\
\text { his or her thoughts, opinions, } \\
\text { and experiences in the } \\
\text { review process }\end{array}$ & $\begin{array}{l}\text { The student seldom included } \\
\text { his or her thoughts, opinions, } \\
\text { and experiences in the } \\
\text { review process. This } \\
\text { information, however, was } \\
\text { not directly related to the } \\
\text { subject matter. }\end{array}$ & $\begin{array}{l}\text { The student included his or } \\
\text { her thoughts, opinions, and } \\
\text { experiences in all phases of } \\
\text { the review process. This } \\
\text { information was directly } \\
\text { related to the subject matter } \\
\text { and highly relevant. }\end{array}$ \\
\hline $\begin{array}{l}\text { Vocabulary, grammar, } \\
\text { punctuation, style, and } \\
\text { terminology }\end{array}$ & $\begin{array}{l}\text { The team frequently used } \\
\text { incorrect grammar, } \\
\text { punctuation, and incomplete } \\
\text { sentences; used terms and } \\
\text { phrases that are not common } \\
\text { to business, marketing, and } \\
\text { social media }\end{array}$ & $\begin{array}{l}\text { The team occasionally used } \\
\text { incorrect grammar, } \\
\text { punctuation, and incomplete } \\
\text { sentences; sometimes used } \\
\text { terms and phrases that are } \\
\text { not common to business, } \\
\text { marketing, and social media }\end{array}$ & $\begin{array}{l}\text { The team consistently used } \\
\text { correct grammar, } \\
\text { punctuation, and complete } \\
\text { sentences and used terms and } \\
\text { phrases that are common to } \\
\text { business, marketing, and } \\
\text { social media }\end{array}$ \\
\hline
\end{tabular}

\begin{tabular}{|l|l|l|l|}
\hline \multicolumn{4}{|c|}{ Grading Rubric: Case Analysis of Emerging Social Media Venues } \\
\hline \multicolumn{1}{|c|}{ Category } & \multicolumn{1}{|c|}{$\mathbf{1}$} & \multicolumn{1}{c|}{$\mathbf{2}$} \\
\hline $\begin{array}{l}\text { Clarity of the synopsis of the } \\
\text { speaker's presentation }\end{array}$ & $\begin{array}{l}\text { The synopsis does not } \\
\text { accurately capture the main } \\
\text { points of the speaker's } \\
\text { presentation }\end{array}$ & $\begin{array}{l}\text { The synopsis captures some } \\
\text { of the main points of the } \\
\text { speaker's presentation }\end{array}$ & $\begin{array}{l}\text { The synopsis clearly and } \\
\text { accurately reflects the main } \\
\text { points of the speaker's } \\
\text { presentation }\end{array}$ \\
\hline $\begin{array}{l}\text { Strategic and tactical } \\
\text { applications and relevance to } \\
\text { marketing }\end{array}$ & $\begin{array}{l}\text { Does not establish the } \\
\text { topic/venue's strategic } \\
\text { and/or tactical applications } \\
\text { to marketing }\end{array}$ & $\begin{array}{l}\text { Establishes some of the } \\
\text { topic/venue's strategic } \\
\text { and/or tactical applications } \\
\text { to marketing }\end{array}$ & $\begin{array}{l}\text { Clearly discusses the } \\
\text { topic/venue's strategic } \\
\text { and/or tactical applications } \\
\text { to marketing }\end{array}$ \\
\hline $\begin{array}{l}\text { Development of thoughts } \\
\text { and ideas }\end{array}$ & $\begin{array}{l}\text { Does not develop main } \\
\text { thoughts and ideas; repeats } \\
\text { thoughts rather than } \\
\text { developing them }\end{array}$ & $\begin{array}{l}\text { Discussion is not clearly } \\
\text { developed and jumps from } \\
\text { one thought to another }\end{array}$ & $\begin{array}{l}\text { Communicates thoughts } \\
\text { clearly and coherently rather } \\
\text { than simply listing ideas. } \\
\text { Connects main threads of } \\
\text { discussion }\end{array}$ \\
\hline $\begin{array}{l}\text { Vocabulary, grammar, } \\
\text { punctuation, and } \\
\text { terminology }\end{array}$ & $\begin{array}{l}\text { Uses incorrect grammar and } \\
\text { punctuation, and incomplete } \\
\text { sentences; uses terms and } \\
\text { phrases that are not common } \\
\text { to business, marketing, and } \\
\text { social media }\end{array}$ & $\begin{array}{l}\text { Sometimes uses incorrect } \\
\text { grammar, punctuation, and } \\
\text { incomplete sentences; } \\
\text { sometimes uses terms that } \\
\text { are not common to business, } \\
\text { marketing, and social media }\end{array}$ & $\begin{array}{l}\text { Uses correct grammar, } \\
\text { punctuation, and complete } \\
\text { sentences; uses terms and } \\
\text { phrases that are common to } \\
\text { business, marketing, and } \\
\text { social media }\end{array}$ \\
\hline
\end{tabular}




\begin{tabular}{|c|c|c|c|c|}
\hline \multicolumn{5}{|c|}{ Grading Rubric: Social Media Tutorial Presentation } \\
\hline Category & 1 & $\mathbf{2}$ & $\mathbf{3}$ & $\mathbf{4}$ \\
\hline Organization & $\begin{array}{l}\text { Presentation cannot be } \\
\text { understood due to } \\
\text { poor organization }\end{array}$ & $\begin{array}{l}\text { Presentation is } \\
\text { difficult to understand } \\
\text { due to poor } \\
\text { organization }\end{array}$ & $\begin{array}{l}\text { Presentation is } \\
\text { organized in a logical } \\
\text { sequence that is easy } \\
\text { to follow }\end{array}$ & $\begin{array}{l}\text { Presentation is } \\
\text { organized in a logical } \\
\text { and interesting } \\
\text { sequence that is easy } \\
\text { to follow }\end{array}$ \\
\hline Subject knowledge & $\begin{array}{l}\text { Team demonstrates no } \\
\text { grasp of information } \\
\text { and cannot answer } \\
\text { questions about } \\
\text { subject material }\end{array}$ & $\begin{array}{l}\text { Team appears } \\
\text { uncomfortable with } \\
\text { information and can } \\
\text { only respond to } \\
\text { elementary questions }\end{array}$ & $\begin{array}{l}\text { Team demonstrates } \\
\text { knowledge of the } \\
\text { subject and can } \\
\text { respond to questions } \\
\text { but fails to elaborate }\end{array}$ & $\begin{array}{l}\text { Team demonstrates } \\
\text { full knowledge (more } \\
\text { than required) by } \\
\text { answering all } \\
\text { questions and readily } \\
\text { offering explanations } \\
\text { and elaboration }\end{array}$ \\
\hline $\begin{array}{l}\text { Graphics and other } \\
\text { visual materials }\end{array}$ & $\begin{array}{l}\text { Team does not use } \\
\text { graphics or other } \\
\text { visual materials in the } \\
\text { presentation }\end{array}$ & $\begin{array}{l}\text { Team seldom uses } \\
\text { graphics and other } \\
\text { visual materials to } \\
\text { support the } \\
\text { presentation }\end{array}$ & $\begin{array}{l}\text { Team uses graphics } \\
\text { and other visual } \\
\text { material that are } \\
\text { related to the } \\
\text { presentation }\end{array}$ & $\begin{array}{l}\text { Team creatively uses } \\
\text { relevant graphics and } \\
\text { other visual material } \\
\text { to explain and } \\
\text { reinforce the } \\
\text { presentation }\end{array}$ \\
\hline Mechanics & $\begin{array}{l}\text { Visual materials } \\
\text { contain numerous } \\
\text { errors in grammar and } \\
\text { spelling; style appears } \\
\text { unprofessional due to } \\
\text { inconsistencies in font, } \\
\text { color schemes, etc. }\end{array}$ & N/A & $\begin{array}{l}\text { Visual materials } \\
\text { contain few grammar } \\
\text { or spelling errors and } \\
\text { are generally } \\
\text { professional in style }\end{array}$ & $\begin{array}{l}\text { Visual materials } \\
\text { contain no grammar or } \\
\text { spelling errors and are } \\
\text { highly professional in } \\
\text { style }\end{array}$ \\
\hline Elocution & $\begin{array}{l}\text { Team presentation is } \\
\text { highly deficient; } \\
\text { presentation is } \\
\text { uncoordinated due to } \\
\text { lack of preparation; } \\
\text { poor or no eye } \\
\text { contact; presentation } \\
\text { is unintelligible due to } \\
\text { pronunciation, tone, } \\
\text { and/or volume; } \\
\text { unprofessional dress; } \\
\text { no enthusiasm or } \\
\text { engagement }\end{array}$ & $\begin{array}{l}\text { Team presentation is } \\
\text { highly unprofessional, } \\
\text { suffers from poor } \\
\text { preparation and } \\
\text { coordination; poor eye } \\
\text { contact; } \\
\text { pronunciation, tone, } \\
\text { and volume } \\
\text { inappropriate for } \\
\text { audience; } \\
\text { unprofessional dress; } \\
\text { lacks enthusiasm and } \\
\text { engagement }\end{array}$ & $\begin{array}{l}\text { Team presentation is } \\
\text { acceptable and } \\
\text { generally well } \\
\text { coordinated; } \\
\text { acceptable level of eye } \\
\text { contact; } \\
\text { pronunciation, tone, } \\
\text { and volume generally } \\
\text { acceptable for } \\
\text { audience; acceptable } \\
\text { dress; generally } \\
\text { enthusiastic and } \\
\text { engaged }\end{array}$ & $\begin{array}{l}\text { Team presentation is } \\
\text { highly professional; } \\
\text { excellent preparation } \\
\text { and coordination; } \\
\text { good eye contact; } \\
\text { pronunciation, tone, } \\
\text { and volume } \\
\text { appropriate for } \\
\text { audience; professional } \\
\text { dress; displays } \\
\text { enthusiasm and } \\
\text { engagement }\end{array}$ \\
\hline
\end{tabular}

Source: The above table was adapted from Information Technology Evaluation Services, NC Department of Public Instruction -http://www.ncsu.edu/midlink/rub.pres.html. 